\title{
Estimasi Model Regresi Binomial Negatif Bivariat (BNBR) Pada Penderita Kusta di Jawa-Timur
}

\author{
Sulantari $^{1}$, Wigid Hariadi ${ }^{2}$ \\ ${ }^{1}$ Pendidikan Matematika, IKIP PGRI Jember, sulantari89@gmail.com \\ ${ }^{2}$ Pendidikan Matematika, IKIP PGRI Jember, wigid.hariadi@gmail.com
}

\begin{abstract}
One of the methods used to overcome overdispersion in poisson regression model is a bivariate negative binomial regression model also known as $B N B R$ Model. Leprosy is a dangerous infectious disease, because it can cause paralysis. Leprosy is divided into 2 types, namely is a leprosy Pausibasilier $(P B)$ type and leprosy Multibasilier $(M B)$ type. Where $P B$ type leprosy is a dry leprosy and $M B$ type leprosy is a wet leprosy. Analysis of the data used to model the number of $P B$ leprosy and $M B$ leprosy cases0and0find out what factor influence it in East Java, the writer uses the BNBR models. Parameter estimation of the BNBR model uses to Maximum likelihood estimation (MLE) methods with NewtonRaphson iterationas well as testing the hypothesis using MLRT methods. After a regression analysis, the results are obtained that of the 10 predictor variables tested, both in $P B$ leprosy and $M B$ leprosy, there are 3 predictor variables that are not significant in the model, namely are: variable percentage of poor population, variable ratio of population who did not graduated SMA, and variable ratio of health facilities.
\end{abstract}

Keywords: Binomial Regression, BNBR, Leprosy, PB Leprosy, MB Leprosy.

Abstrak. Salah satu metode yang digunakan untuk mengatasi overdispersi dalam regresi Poisson yakni dengan regresi binomial negatif bivariat atau dikenal juga dengan model regresi $B N B R$. Penyakit Kusta adalah salah satu penyakit menular yang berbahaya, karena dapat menyebabkan kelumpuhan. Jenis penyakit kusta terbagi menjadi 2, yakni Kusta tipe Pausibasiler $(P B)$ dan tipe Multibasiler. $(M B)$. Dimana kusta tipe PB merupakan Kusta kering, dan kusta tipe MB adalah kusta basah. Analisis data yang digunakan untuk memodelkan besarnya jumlah kasus kusta tipePB0dan tipe MB, kemudian untuk mengetahui faktor apa saja yang mempengaruhinya di Jawa Timur, penulis menggunakan model BNBR. Penaksiran parameter model BNBR menggunakan Maximum Likelihood Estimation (MLE) dengan iterasi Newton-Raphson serta melakukan pengujian hipotesis menggunakan metode MLRT. Setelah dilakukan analisis regresi, diperoleh hasil bahwa dari 10 variabel prediktor yang diujikan, baik pada kusta tipe PB maupun tipe MB, terdapat 3 variabel prediktor yang tidak signifikan dalam model, yakni: variabel presentase penduduk miskin, variabel rasio penduduk yang tidak tamat SMA, dan variabel rasio sarana kesehatan.

Kata kunci: Regresi Binomial, BNBR, Kusta, Kusta tipe PB, Kusta tipe MB. 


\section{Pendahuluan}

Model regresi banyak diaplikasikan di berbagai bidang ilmu, diantaranya bidang industri, farmasi, agrikultur, teori antrian, sosiologi, demografi, dan lain sebagainya. Menurut Hilbe [4], model regresi poisson memiliki asumsi yang spesifik, yaitu variansi dari variabel respon sama dengan mean, keadaan seperti ini dikenal dengan istilah ekuidispersi. Namun ekuidispersi pada data sangat jarang terjadi, karena pada umumnya sering ditemui data diskrit dengan varians lebih besar dibandingkan dengan mean, atau disebut dengan istilah overdispersi. Salah satu metode yang dapat digunakan dalam mengatasi overdispersi pada model regresi poisson adalah regresi binomial negatif. Salah satu perkembangan dari model regresi binomial negatif adalah model regresi binomial negatif bivariat (BNBR). Dengan menggunakan model ini, mampu melakukan estimasi model dengan lebih baik pada model regresi yang mengalami overdispersi.

Penyakit kusta merupakan suatu penyakit menular yang disebabkan oleh infeksi bakteri Mycobacterium leprae atau biasa disebut kuman kusta. Kuman kusta dapat hidup diluar tubuh manusia antara 1-9 hari tergantung pada suhu atau cuaca, dan diketahui hanya kusta yang utuh (solid) saja yang dapat menimbulkan penularan [5]. Penyakit Kusta cukup berbahaya, karena penyakit ini dapat menyebabkan kelumpuhan pada penderitanya. Penyakit kusta dibagi menjadi dua jenis, yakni kusta tipe PB (Pausibasilier)dan kusta tipe MB (Multibasilier). Kusta tipe PB disebut juga kusta kering, dan kusta tipe MB disebut juga kusta basah. Provinsi Jawa Timur menjadi penyumbang pasien kusta terbanyak di antara provinsi lainnya. Rata-rata penemuan penderita kusta di Provinsi Jawa Timur per tahun antara 4.000-5.000 orang. Pada tahun 2012 penemuan penderita baru di Provinsi Jawa Timur sebanyak 4.842 orang, jumlah ini merupakan jumlah tertinggi diantara provinsi lainnya [1].

Ada banyak faktor yang diduga menjadi penyebab dari penyakit kusta. Ada beberapa orang yang sudah melakukan penelitian mengenai penyakit kusta ataupun faktor-faktor penyebabnya. Namun demikan, penelitian-penelitian tersebut belumlah sempurna. Simunati [8] berpendapat bahwa faktor yang mempengaruhi kejadian penyakit kusta menunjukkan adanya pengaruh riwayat kontak, status gizi dan perilaku hidup bersih terhadap kejadian penyakit kusta di wilayah kota Makassar. Norlatifah, dkk [6] juga meneliti tentang faktor yang mempengaruhi penyakit kusta di kabupaten Tapin Provinsi Kalimantan Timur, penelitian ini memberikan hasil bahwa kondisi fisik rumah, riwayat kontak dan tingkat pendidikan mempengaruhi jumlah kejadian penyakit kusta. Dari pendapat diatas, terlihat bahwa terdapat banyak faktor yang menjadi penyebab penyakit kusta. Baik itu dari faktor internal pasien, ataupun faktor eksternal (lingkungan). Masalah penyakit kusta ini terjadi di hamper seluruh wilayah Indonesia. Karena nya penting untuk menjadi perhatian secara serius.

Oleh karena tingginya jumlah orang yang terserang penyakit Kusta di Provinsi Jawa Timur inilah, penulis berkeinginan untuk mencari tahu tentang faktor-faktor apa saja-yang-menjadi sebab penyebaran penyakit kusta di Jawa Timur, sehingga berdasarkan hal itu, penulis dapat mengetahui bagaimana bentuk model regresi BNBR yang terbentuk. Dengan harapan, berdasarkan model tersebut, pemerintah dan masyarakat dapat bersama-sama menekan penyebaran penyakit kusta, khususnya untuk wilayah Jawa Timur. 


\section{Tinjauan Pustaka}

\subsection{Jenis Penelitian dan Sumber Data}

Penelitian ini merupakan penelitian terapan dan kuantitatif. Karena data yang gunakan adalah data kuantitatif. Sedangkan menurut metodenya, tulisan ini merupakan penelitian historis. Data yang penulis gunakan adalah data sekunder dimana datanya berasal dari data profil kesehatan provinsi Jawa Timur tahun 2012. Dimana unit observasinya adalah kabupaten dan kota di Jawa Timur. Provinsi Jawa Timur terdiri dari 29 kabupaten serta 9 kota, sehingga jumlah unit observasinya sebanyak 38 kabupaten /kota.

\subsection{Model Regresi Binomial Negatif Binomial}

Menurut Famoye [2], model regresi binomial negatif bivariat seperti pada persamaan berikut :

$$
\begin{gathered}
\mu_{j i}=e^{X_{i}^{T} \beta_{j}} ; \mathrm{j}=1,2 \\
\mathbf{x}_{i}=\left[\begin{array}{lllll}
1 & x_{1 i} & x_{2 i} & \ldots & x_{k i}
\end{array}\right]^{T} \\
\boldsymbol{\beta}_{j}=\left[\begin{array}{lllll}
\beta_{j 0} & \beta_{j 1} & \beta_{j 2} & \ldots & \beta_{j k}
\end{array}\right]^{T}
\end{gathered}
$$

Dengan $i=1,2, \ldots, n$, adalah observasi, dimana observasi digunakan dalam model $\mu_{i}$ dan $\boldsymbol{\beta}_{j}$ menunjukkan vektor korespondensi dari koefisien regresi.

\subsection{Estimasi Parameter Regresi Binomial Negatif Bivariat}

Menurut Park, dkk [8], estimasi parameter model regresi binomial negatif dapat menggunakan metode Maximum Likelihood Estimator(MLE) dengan menggunakan prosedur-iterasi Newton-Rhapson. Sehingga dalam regresi binomial negative bivariat ini metode estimasi parameter yang digunakan adalah metode Maximum Likelihood Estimation (MLE) secara matematis fungsi likelihood-nya dapat ditulis sebagai berikut :

$$
L\left(\boldsymbol{\beta}_{1}, \boldsymbol{\beta}_{2}, \tau\right)=\prod_{i=1}^{n}\left(\frac{\Gamma\left(\tau^{-1}+y_{1 i}+y_{2 i}\right)}{\Gamma\left(\tau^{-1}\right) \Gamma\left(y_{1 i}+1\right) \Gamma\left(y_{2 i}+1\right)} \mu_{1 i}^{y_{1 i}} \mu_{2 i}^{y_{2 i}} \tau^{-\tau^{-1}}\left(\tau^{-1}+y_{1 i}+y_{2 i}\right)^{-\left(\tau^{-1}+y_{1 i}+y_{2 i}\right)}\right)
$$

Dengan fungsi Gamma menurut Gurmu [3] adalah :

$$
\begin{aligned}
& \frac{\Gamma\left(\tau^{-1}+y_{1 i}+y_{2 i}\right)}{\Gamma\left(\tau^{-1}\right)}= \prod_{k=1}^{y_{1 i}+y_{2 i}}\left(y_{1 i}+y_{2 i}+\tau^{-1}-k\right) \\
& Q=\ln L\left(\boldsymbol{\beta}_{1}, \boldsymbol{\beta}_{2}, \tau\right)=\sum_{i=1}^{n}\left[\sum_{k=1}^{y_{1 i}+y_{2 i}} \ln \left(y_{1 i}+y_{2 i}+\tau^{-1}-k\right)+y_{1 i} \ln \mu_{1 i}+y_{2 i} \ln \mu_{2 i}-\ln \tau / \tau\right. \\
&\left.\left.\quad-\left(\tau^{-1}+y_{1 i}+y_{2 i}\right) \ln \left(\tau^{-1}+\mu_{1 i}+\mu_{2 i}\right)-\ln \left(y_{1 i} !\right)-\ln \left(y_{2 i} !\right)\right)\right]
\end{aligned}
$$

Dengan :

$$
\mu_{1 i}=\exp \left(\mathbf{x}_{i}^{T} \boldsymbol{\beta}_{1}\right) \text { dan } \mu_{2 i}=\exp \left(\mathbf{x}_{i}^{T} \boldsymbol{\beta}_{2}\right)
$$

Proses untuk mendapatkan penaksir parameter dari model ini adalah dengan cara diturunkan terhadap masing-masing parameternya kemudian di samakan 
dengan nol. Namun hasilnya tidak dapat diselesaikan secara analitik, sehingga perlu digunakan prosedur iterative.

\subsection{Pengujian Parameter Model Regresi Binomial Negatif Bivariat}

Menurut Park, dkk [7], dalam menentukan nilai statistik uji, terlebih dahulu tentukan dua buah fungsi likelihood yang berhubungan dengan model regresi yang diperoleh. Fungsi fungsi likelihood yang dimaksud adalah $L(\hat{\Omega})$ yaitu nilai maximum likelihood untuk model yang lebih lengkap dengan melibatkan variabel independen dan fungsi $L(\hat{\omega})$, yaitu nilai maximum likelihood untuk model sederhana tanpa melibatkan variabel prediktor. Salah satu metode yang0dapat digunakan untuk menentukan nilai statistik uji dalam uji estimasi parameter adalah menggunakan metode Maximum Likelihood Ratio Test (MLRT):

$$
D(\hat{\boldsymbol{\beta}})=-2 \ln \Lambda=-2 \ln \left(\frac{L(\hat{\omega})}{L(\hat{\Omega})}\right)=2(\ln L(\hat{\Omega})-\ln L(\hat{\omega}))
$$

Dengan menggunakan Hipotesis:

$H_{0}: \beta_{j 1}=\beta_{j 2}=\ldots=\beta_{j l}=0 ; j=1,2 ; l=1,2,3, \ldots, m$

$H_{1}$ : paling sedikit ada satu $\beta_{j l} \neq 0$;

$D(\hat{\boldsymbol{\beta}})$ merupakan devians model regresi binomial negatif bivariat dengan menggunakan pendekatan distribusi chi-square dengan degree of freedom $v$ dan daerah kritisnya adalah tolak $\mathrm{H}_{0}$ jika $D(\hat{\boldsymbol{\beta}})_{>} \chi^{2}{ }_{(\alpha ; v)}$, dengan $v$ adalah derajat bebas yang diperoleh dari banyaknya0parameter model di bawah populasi dikurangi banyaknya parameter di bawah $\mathrm{H}_{0}$. Uji signifikansi parameter untuk variabel independen adalah dengan menggunakan hipotesis :

$H_{0}: \beta_{j l}=0$

$H_{1}: \beta_{j l} \neq 0 ; j=1,2 ; l=1,2, \ldots, k$

Statistik uji yang digunakan adalah :

$z=\frac{\hat{\beta}_{j l}}{\operatorname{se}\left(\hat{\beta}_{j l}\right)}$

Daerah kritis : tolak $H_{0}$ jika $\left|z_{\text {hitung }}\right|>z_{\alpha / 2}$

\section{Pembahasan}

Provinsi Jawa Timur terdiri dari 38 wilayah kabupaten dan kota yang terbagi menjadi 29 kabupaten serta 9 kota. Berdasarkan hasil sebuah survei yang dilakukan oleh Kementerian Kesehatan Republik Indonesia pada tahun 2012, menempatkan Provinsi Jawa Timur menjadi penyumbang jumlah penderita kusta terbanyak di antara provinsi lainnya. Pada tahun 2012, banyaknya kasus penderita kusta baru di Indonesia sebanyak 18.853 kasus, sedangkan penemuan kasus penderita baru penyakit kusta di Jawa Timur ada sebanyak 4.842 kasus (25,5\% dari total kasus baru di Indonesia). Berdasarkan jumlah kasus penderita kusta tersebut, jumlah kasus penderita kusta PBisebanyak 341 kasus sedangkan 
jumlah kasus penderita kusta MB sebanyak 4.501 kasus. Untuk lebih jelasnya akan terlihat pada Gambar 1 dibawah ini.

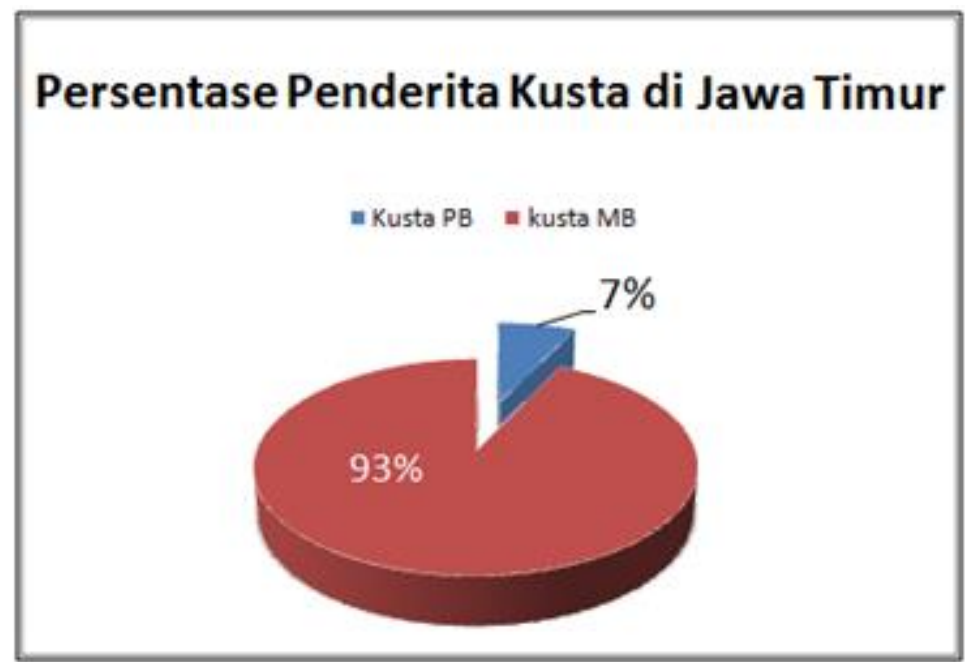

Gambar 1: Diagram Persentase Penderita Kusta di Jawa Timur Tahun 2012.

Dalam penelitian ini terdapat sepuluh variabel independen yang penulis duga berpengaruh terhadap jumlah kasus penderita kusta PB dan MB di Jawa Timur. Dimana variabel yang digunakan adalah:

Tabel 1 : Variabel Yang Digunakan

\begin{tabular}{|c|c|}
\hline Variabel & Keterangan \\
\hline $\mathrm{Y}$ & Jumlah kasus kusta PB \\
\hline $\mathrm{X}_{1}$ & Presentase penduduk miskin \\
\hline $\mathrm{X}_{2}$ & Persentase rumah tangga ber PHBS \\
\hline $\mathrm{X}_{3}$ & Persentase kegiatan penyuluhan kesehatan \\
\hline $\mathrm{X}_{4}$ & Rasio tenaga medis per 100000 penduduk \\
\hline $\mathrm{X}_{5}$ & Persentase rumah sehat \\
\hline $\mathrm{X}_{6}$ & $\begin{array}{l}\text { Presentase penduduk yang mengobati } \\
\text { penyakit sendiri }\end{array}$ \\
\hline $\mathrm{x}_{7}$ & Presentase penduduk yang tidak tamat SD \\
\hline $\mathrm{X}_{8}$ & $\begin{array}{l}\text { Rasio penduduk yang tidak tamat SMA per } 100000 \\
\text { penduduk }\end{array}$ \\
\hline $\mathrm{X}_{9}$ & $\begin{array}{l}\text { Presentase penduduk yang melakukan } \\
\text { keterbukaan informasi }\end{array}$ \\
\hline $\mathrm{X}_{10}$ & Rasio sarana kesehatan \\
\hline
\end{tabular}

Berdasarkan variabel yang disebutkan pada Tabel 1, penulis melakukan pengumpulan data, kemudian melakukan analisis data. Analisis statistik deskriptif dari data tersebut tersaji dalam Tabel 2 dibawah ini: 
Tabel 2 : Rangkuman Statistik Deskriptif Dari Variabel.

\begin{tabular}{|lrrrrr|}
\hline \hline \multicolumn{1}{c}{ Variabel } & \multicolumn{1}{c}{ Mean } & \multicolumn{1}{c}{ Min } & \multicolumn{1}{c}{ Maks } & \multicolumn{1}{c}{ StDev } & CoefVar \\
\hline Jumlahkusta PB & 8,97 & 0,00 & 71,00 & 14,29 & 159,2 \\
Jumlah kustaMB & 118,45 & 0,00 & 553,00 & 135,9 & 114,73 \\
$\begin{array}{l}\text { Persentase penduduk } \\
\text { miskin }\end{array}$ & 32,39 & 13,24 & 62,39 & 13,02 & 40,21 \\
$\begin{array}{l}\text { Persentase RT ber PHBS } \\
\text { Rasio kegiatan }\end{array}$ & 43,72 & 8,50 & 65,74 & 14,79 & 33,82 \\
penyuluhankesehatan & 1,30 & 0,09 & 4,05 & 1,058 & 81,23 \\
$\begin{array}{l}\text { Rasio tenagamedis per } \\
\begin{array}{l}\text { 100000 penduduk } \\
\text { Persentase numahsehat }\end{array}\end{array}$ & 25,49 & 3,51 & 167,03 & 34,35 & 134,75 \\
$\begin{array}{l}\text { Presentase penduduk } \\
\text { yangmengobatipenyakit }\end{array}$ & 63,94 & 48,53 & 84,59 & 9,39 & 14,68 \\
$\begin{array}{l}\text { sendiri } \\
\begin{array}{l}\text { Presentase penduduk } \\
\text { yangtidak tamat SD }\end{array}\end{array}$ & 15,12 & 5,79 & 27,65 & 125,9 & 54,33 \\
$\begin{array}{l}\text { Rasio pendudukyang } \\
\text { tidak tamat SMAper }\end{array}$ & 231,74 & 54,00 & 632,00 & 5,563 & 36,8 \\
$\begin{array}{l}\text { 100000 penduduk } \\
\text { Presentase penduduk }\end{array}$ & 30,23 & 20,80 & 43,20 & 5,288 & 17,49 \\
$\begin{array}{l}\text { yangmelakukan } \\
\text { keterbukaaninformasi } \\
\text { Rasio saranakesehatan }\end{array}$ & 1546,11 & 200,00 & 3362,00 & 845 & 54,62 \\
\hline \hline
\end{tabular}

Dari Tabel 2, memperlihatkan rangkuman statistik deskriptif mengenai jumlah penderita kusta di wilayah provinsi Jawa Timur. Dari analisis statistik deskriptif yang telah dilakukan, diperoleh hasil bahwa rata-rata jumlah kasus kusta PB di setiap kabupaten atau kota di Jawa Timur sebesar 8,97. Dengan nilai jumlah kasus tertinggi penderita kusta PB adalah di Kabupaten Sumenep (71kasus). Sedangkan untuk nilai rata-rata pada jumlah kasus kusta MB untuk setiap kabupaten/kota di Jawa Timur sebesar 118,4, dengan jumlahitertingginya adalah di Kab Sampang (553 kasus). Untuk selanjutnya pada besaran variasi antar variabel, terlihat bahwa variabel rasio tenaga medis per-100.000 penduduk $\left(X_{4}\right)$ mempunyai nilai koefisien variasi yang lebih tinggi dari variabel lainnya. Rata-rata persentase penduduk miskin $\left(X_{1}\right)$ di masing-masing kabupaten atau kota di provinsi Jawa Timur sebesar 32,39, dengan kabupaten Bondowoso mempunyai nilai persentase tertinggi yakni sebesar 62,39, danikota Batu memiliki persentase terendah yakni sebesar 13,24. Nilai rata-rata persentase rumah tangga ber-PHBS $\left(X_{2}\right)$ di provinsi Jawa Timur sebesar 43,72, dimana kota Kediri memiliki nilai persentase tertinggi (sebesar 65,74), dan kabupaten Pamekasan memiliki nilai persentase terendah (sebesar 8,50). Nilai rata-rata persentase kegiatan penyuluhan kesehatan $\left(X_{3}\right)$ sebesar 1,3, dengan kota Pasuruan yang memiliki persentase tertinggi (sebesar 4,05), dengan kabupaten Gresik memiliki persentase terendah (sebesar 0,09). Untuk rata-rata rasio tenaga medis $\left(X_{4}\right)$ sebesar 25,49, dimana kota Madiun memiliki nilai persentase tertinggi (sebesar 167,03), dan kabupaten Sumenep memiliki persentase terendah (sebesar 3,51). Nilai rata-rata persentase rumah sehat $\left(X_{5}\right)$ sebesar 67,84, dimana kabupaten Gresik memiliki persentase tertinggi (sebesar 87,17), dan kabupaten Probolinggo memiliki nilai persentase yang terendah (sebesar 38,29).

Rata-rata nilai persentase penduduk yang mengobati penyakit sendiri $\left(X_{6}\right)$ adalah sebesar 63,94, dimana0kota Kediri memiliki persentase tertinggi (sebesar 
84,59), dan kota Pasuruan memiliki nilai persentase terendah (sebesar 48,53). Rata-rata besarnya persentase penduduk yang tidak tamat $\mathrm{SD}\left(X_{7}\right)$ adalah sebesar 15,12, dimana kabupaten Probolinggo memiliki persentase tertinggi (sebesar 27,65) dan kota Madiun memiliki persentase0terendah (sebesar 5,79). Rata-rata besarnya rasio penduduk yang tidak tamat $\operatorname{SMAi}\left(X_{8}\right)$ adalahi(sebesar 231,74), dan kota Probolingg yang memiliki persentase tertinggi (sebesar 632), serta kabupaten Jember memiliki persentase terendah (sebesari54). Rata-rata nilai persentase penduduk yang melakukan keterbukaan informasi $\left(X_{9}\right)$ adalah sebesar 30,23, dengan kota Malang memiliki persentase tertinggi (sebesar043,2), dan kabupaten Sampang memiliki persentase terendah (sebesar 20,80). Rata-rata besarnya rasio sarana kesehatan $\left(X_{10}\right)$ adalah sebesar 1546,11 , dimana kabupaten Malang memiliki persentase tertinggi (sebesar 3362), sedangkan kota Mojokerto memiliki persentase terendah (sebesar 200).

\subsection{Pengujian Korelasi Variabel Respon}

Asumsi Multikolinieritas berpengaruh besar terhadap estimasi parameter. Pertama-tama akan dilakukan pemeriksaan dahulu, apakah terdapat kasus multikolinieritas antar variabel independen atau tidak. Salah satu cara yang dapat digunakan untuk memeriksa kasus multikolinieritas yakni dengan memeriksa nilai korelasi antar variabel independen. jika nilai tersebut lebih besar dari 0,95 atau lebih kecil dari -0,95, maka dapat dikatakan terjadi multikolinieritas. Rangkuman nilai korelasi variabel prediktor tersaji pada Tabel 3 dibawah ini.

Tabel 3 : Tabel Nilai Koefisien Korelasi Variabel Independen

\begin{tabular}{|lccccccccc|}
\hline \hline & X1 & X2 & X3 & X4 & X5 & X6 & X7 & X8 & X9 \\
\hline X2 & $-0,37$ & & & & & & & & \\
X3 & 0,02 & 0,08 & & & & & & & \\
X4 & $-0,36$ & 0,09 & 0,49 & & & & & & \\
X5 & $-0,52$ & 0,49 & 0,08 & 0,04 & & & & & \\
X6 & 0,07 & 0,01 & $-0,04$ & 0,23 & 0,03 & & & & \\
X7 & $-0,02$ & $-0,09$ & 0,34 & 0,15 & $-0,01$ & 0,09 & & & \\
X8 & 0,65 & $-0,47$ & $-0,23$ & $-0,53$ & $-0,65$ & $-0,04$ & $-0,06$ & & \\
X9 & $-0,65$ & 0,41 & 0,10 & 0,56 & 0,56 & 0,08 & 0,10 & $-0,78$ & \\
X10 & 0,14 & 0,28 & $-0,49$ & $-0,58$ & 0,001 & $-0,08$ & $-0,33$ & 0,30 & $-0,23$ \\
\hline \hline
\end{tabular}

Berdasarkan Tabel 3 diatas, terlihat bahwa tidak terdapat nilai koefisien korelasi antar variabel independen yang melebihi nilai $\pm 0,95$. Sehingga kuat dugaan bahwa tidak terjadi masalah multikolinearitas dalam model. Namun demikian, untuk memastikan multikolinearitas secara akurat yakni dengan menggunakan nilai kriteria VIF. Nilai VIF yang lebih besar dari 10 merupakan bukti adanya kasus multikolinieritas yang terjadi pada model. Oleh karena itu, penulis melakukan pengujian VIF, dan hasil dari pengujian tersebut disajikan pada Tabel 4 dibawah ini. 
Tabel 4 : Nilai VIF dari Variabel Independen

\begin{tabular}{|c|c|c|c|c|c|}
\hline Variabel & X1 & $\mathrm{X} 2$ & X3 & $\mathrm{X} 4$ & X5 \\
\hline VIF & 2,143 & 1,934 & 2,066 & 2,863 & 2,013 \\
\hline Variabel & X6 & $\mathrm{X} 7$ & X8 & $\mathrm{Xg}$ & X10 \\
\hline VIF & 1,187 & 3,975 & 1,271 & 3,391 & 2,367 \\
\hline
\end{tabular}

Berdasarkan Tabel 4, dapat terlihat bahwa variabel independen memiliki nilai VIF $<10$, berdasarkan hal ini dapat disimpulkan bahwa tidak terdapat kasus multikolinieritas pada semua variabel independen yang digunakan dalam model. sehingga, disimpulkan bahwa semua variabel independen tersebut bisa digunakan dalam pemodelan regresi $B N B R$.

\subsection{Pemodelan Regresi BNBR Pada Penderita Kusta PB dan MB}

Uji signifikansi regresi $B N B R$ secara overall dilakukan dalam rangka untuk menguji apakah secara bersama-sama semua variabel independen yang diujikan berpengaruh terhadap model atau tidak, hipotesis nya adalah:

$$
\begin{aligned}
& H_{0}: \beta_{j 1}=\beta_{j 2}=\ldots=\beta_{j 10} ; j=1,2 \\
& H_{1}: \text { paling tidak ada satu } \beta_{j l} \neq 0 ; j=1,2, l=1,2, . ., 10
\end{aligned}
$$

Kebaikan model regresi $B N B R$ dapat dilihat dengan melihat nilai devians dariOmodel yang terbentuk. Berdasarkan hasil perhitungan, diperoleh hasil bahwa nilai $D(\hat{\boldsymbol{\beta}})=161,351$ dan nilai $\chi_{(0,05 ; 2)}^{2}=31,41$. Karena hasil tersebut, maka, keputusannya adalah tolak $\mathrm{H}_{0}$, karena nilai $D(\widehat{\boldsymbol{\theta}})>\chi_{(0,05 ; 10)}^{2}$. Yang bermakna bahwa semua parameter secara bersama-sama memiliki pengaruh dalam model. Untuk selanjutnya perlu dilakukan uji parameter secara parsial pada regresi $B N B R$ khusus penderita kusta tipe $P B$. Rangkuman hasil estimasi parameter regresi $B N B R$ pada Kusta tipe $P B$ tersaji pada Tabel 5 dibawah ini:

Tabel 5 : Estimasi Parameter Regresi $B N B R$ Pada Kusta tipe $P B$ di Provinsi Jawa Timur Tahun 2012.

\begin{tabular}{|c|r|r|r|r|}
\hline \multirow{2}{*}{ Parameter } & \multicolumn{4}{|c|}{ Kusta PB $\left(\mathbf{Y}_{1}\right)$} \\
\cline { 2 - 5 } & \multicolumn{1}{|c|}{ Taksiran } & \multicolumn{1}{c|}{ SE } & \multicolumn{1}{c|}{$\mathrm{Z}_{\text {ans }}$} & p-value \\
\hline$\beta_{0}$ & 71,1539 & 1,2685 & 56,0927 & 0,0000 \\
\hline$\beta_{1}$ & 0,2930 & 2,0946 & 0,1399 & 0,8888 \\
\hline$\beta_{2}$ & $-0,7657$ & 0,1017 & $-7,5288$ & 0,0000 \\
\hline$\beta_{3}$ & $-1,9786$ & 0,9294 & $-2,1289$ & 0,0333 \\
\hline$\beta_{4}$ & 1,2547 & 0,5175 & 2,4247 & 0,0153 \\
\hline$\beta_{5}$ & 3,4332 & 1,0835 & 3,1685 & 0,0015 \\
\hline$\beta_{6}$ & 4,0081 & 1,2631 & 3,1733 & 0,0015 \\
\hline$\beta_{7}$ & $-4,4729$ & 1,0731 & $-4,1683$ & 0,0000 \\
\hline$\beta_{3}$ & 0,3254 & 0,7448 & 0,4368 & 0,6622 \\
\hline$\beta_{9}$ & $-12,4187$ & 0,8020 & $-15,4845$ & 0,0000 \\
\hline$\beta_{30}$ & 0,1232 & 0,2490 & 0,4947 & 0,6208 \\
\hline
\end{tabular}

Berdasarkan Tabel 5 diatas, dengan menggunakan tingkat signifikansi $\alpha=5 \%$ dapat dilihat bahwa terdapat 7 variabel independen dengan nilai $Z_{\text {hitung }}>Z_{\alpha / 2}=1,96$ Sehingga dapat dikatakan bahwa terdapat 7 variael yang signifikan dalam model. Sementara terdapat 3 variabel yang belum signifikan dalam model, yakni variabel 
$\mathrm{X}_{1}, \mathrm{X}_{8}$, dan $\mathrm{X}_{10}$. Namun karena penulis menganggap ketiga variabel tersebut merupakan variabel yang penting, maka penulis tetap memasukkan ketiga variabel tersebut kedalam model regresi $B N B R$. Sehingga berdasarkan Tabel 5 diatas, dapat dituliskan model Regresi BNBR untuk penderita kusta tipe PB di provinsi Jawa Timur tahun 2012 adalah sebagai berikut:

$$
\begin{gathered}
\hat{\mu}_{1}=\exp \left(71,1539+0,2930 X_{1}-0,7657 X_{2}-1,9786 X_{3}+1,2547 X_{4}+3,4332 X_{5}+4,0081 X_{6}\right. \\
\left.-4,4729 X_{7}+0,3254 X_{8}-12,4187 X_{9}+0,1232 X_{10}\right)
\end{gathered}
$$

Rangkuman hasil estimasi parameter model regresi $B N B R$ pada Kusta tipe $M B$ tersaji pada Tabel 6 dibawah ini:

Tabel 6 : Estimasi Parameter Regresi $B N B R$ pada Kusta tipe $M B$ di Provinsi Jawa Timur Tahun 2012.

\begin{tabular}{|c|r|r|r|r|}
\hline \multirow{2}{*}{ Parameter } & \multicolumn{4}{|c|}{ Kusta MB $\left(\mathbf{Y}_{2}\right)$} \\
\cline { 2 - 5 } & Taksiran & \multicolumn{1}{|c|}{ SE } & \multicolumn{1}{c|}{$\mathrm{Z}_{\text {mans }}$} & \multicolumn{1}{c|}{ p-value } \\
\hline$\beta_{0}$ & 39,3043 & 0,5315 & 73,9541 & 0,0000 \\
\hline$\beta_{1}$ & 0,5141 & 1,2036 & 0,4271 & 0,6693 \\
\hline$\beta_{2}$ & $-2,3989$ & 0,6727 & $-3,5662$ & 0,0004 \\
\hline$\beta_{3}$ & 20,2960 & 0,6170 & 32,8925 & 0,0000 \\
\hline$\beta_{4}$ & 2,5700 & 0,5926 & 4,3368 & 0,0000 \\
\hline$\beta_{5}$ & 3,5228 & 1,2995 & 2,7108 & 0,0067 \\
\hline$\beta_{6}$ & 3,8960 & 0,5870 & 6,6374 & 0,0000 \\
\hline$\beta_{7}$ & $-7,0472$ & 1,6956 & $-4,1563$ & 0,0000 \\
\hline$\beta_{8}$ & 0,2296 & 0,8010 & 0,2867 & 0,7744 \\
\hline$\beta_{9}$ & $-10,4159$ & 0,8376 & $-12,4350$ & 0,0000 \\
\hline$\beta_{10}$ & 0,1723 & 0,3230 & 0,5335 & 0,5937 \\
\hline
\end{tabular}

Berdasarkan Tabel 6 diatas, dengan menggunakan tingkat signifikansi $\alpha=5 \%$ dapat dilihat bahwa terdapat 7 variabel independen dengan nilai $Z_{\text {hitung }}>Z_{\alpha / 2}=1,96$ Sehingga dapat dikatakan bahwa terdapat 7 variabel yang signifikan dalam model. Sementara terdapat 3 variabel yang tidak signifikan dalam model, yakni variabel $\mathrm{X}_{1}, \mathrm{X}_{8}$, dan $\mathrm{X}_{10}$. Namun karena penulis menganggap ketiga variabel tersebut merupakan variabel yang penting, maka penulis tetap memasukkan ketiga variabel tersebut kedalam model regresi BNBR. Sehingga berdasarkan Tabel 6 diatas, dapat dituliskan model Regresi BNBR untuk penderita kusta tipe MB diiprovinsi Jawa Timur tahun 2012 adalah sebagai berikut:

$$
\begin{gathered}
\hat{\mu}_{2}=\exp \left(39,3043+0,5141 \mathrm{X}_{1}-2,3989 \mathrm{X}_{2}+20,2960 \mathrm{X}_{3}+2,5700 \mathrm{X}_{4}+3,5228 \mathrm{X}_{5}+3,8960 \mathrm{X}_{6}\right. \\
\left.-7,0472 \mathrm{X}_{7}+0,2296 \mathrm{X}_{8}-10,4159 \mathrm{X}_{9}+0,1723 \mathrm{X}_{10}\right)
\end{gathered}
$$

Berdasarkan model regresi BNBR yang diperoleh, maka dapat dilakukan simulasi / prediksi perhitungan mengenai penyebaran penyakit kusta di Jawa Timur baik itu kusta tipe PB maupun tipe MB. Sehingga diharapkan penyebaran penyakit kusta di Jawa Timur dapat di cegah/tekan/diturunkan. 


\section{Kesimpulan}

1. Model regresi binomial negatif bivariat (BNBR) untuk-penderita kusta tipe $P B$ di Jawa Timur tahun 2012 yang terbentuk adalah:

$$
\begin{gathered}
\hat{\mu}_{1}=\exp \left(71,1539+0,2930 \mathrm{X}_{1}-0,7657 \mathrm{X}_{2}-1,9786 \mathrm{X}_{3}+1,2547 \mathrm{X}_{4}+3,4332 \mathrm{X}_{5}+4,0081 \mathrm{X}_{6}\right. \\
\left.-4,4729 \mathrm{X}_{7}+0,3254 \mathrm{X}_{8}-12,4187 \mathrm{X}_{9}+0,1232 \mathrm{X}_{10}\right)
\end{gathered}
$$

2. Model regresi binomial negatif bivariat (BNBR) untuk penderita kusta tipe $M B$ di Jawa Timur tahun 2012 yang terbentuk adalah:

$$
\begin{gathered}
\hat{\mu}_{2}=\exp \left(39,3043+0,5141 X_{1}-2,3989 X_{2}+20,2960 X_{3}+2,5700 X_{4}+3,5228 X_{5}+3,8960 X_{6}\right. \\
\left.-7,0472 X_{7}+0,2296 X_{8}-10,4159 X_{9}+0,1723 X_{10}\right)
\end{gathered}
$$

\section{Daftar Pustaka}

[1] Anonim. 2013. Profil Kesehatan Indonesia Tahun 2012. Kemenkes RI Press. Jakarta.

[2] Famoye, F. 2010. On the Bivariate Negative Binomial Regression Model. Journal of Applied Statistics. Vol 37, No. 6,.hal.969-981.

[3] Gurmu, S. 1991. Test of Detecting Overdispersion in the Positive Poisson Regression Model. Journal of Business and Economics Statistics .Vol.9, No. 2, pp. 215-222.

[4] Hilbe, J. M. 2011. Negative Binomial Regression (Edisi kedua). Cambridge University Press. UK.

[5] Hiswani. 2001. Kusta Salah Satu Penyakit Menular Yang Masih Di Jumpai Di Indonesia. Universitas Sumatera Utara Press. Medan.

[6] Norlatifah, Sutomo. A.H., dan Solikhah. 2010. Hubungan Kondisi Fisik Rumah, Sarana Air Bersih Dan Karakteristik Masyarakat Dengan Kejadian Kusta Di Kabupaten Tapin Kalimantan Selatan. Jurnal KES MAS. Vol 3. No. 1 ISSN : 1978-0575.

[7] Park, B.J., dan Lord, D. 2008. Adjusment for The Maximum Likelihood Estimate of The Negative Binomial Dispersion Parameter. Texas University Press. USA.

[8] Simunati, 2013.Faktor-Faktor Yang Mempengaruhi Kejadian Penyakit Kusta Di Poliklinik Rehabilitasi Rumah Sakit Dr.Tadjuddin.Chalid Makassar.Jurnal Poltekkes Kemenkes Makassar. Vol 3. No. 1. ISSN : 23021721. 